\title{
Pengaruh keadaan rongga mulut, perilaku ibu, dan lingkungan terhadap risiko karies pada anak
}

\author{
Quroti A'yun*, Julita Hendrartini**, Al Supartinah*** \\ *Jurusan Keperawatan Gigi, Politeknik Kesehatan Kementerian Kesehatan Yogyakarta, Yogyakarta, Indonesia \\ **Departemen IImu Kesehatan Gigi Pencegahan dan IImu Kesehatan Gigi Masyarakat, Fakultas kedokteran Gigi, Universitas Gadjah \\ Mada Yogyakarta, Yogyakarta, Indonesia \\ ***Departemen IImu Kedokteran Gigi Anak, Fakultas Kedokteran Gigi, Universitas Gadjah Mada, Yogyakarta, Indonesia \\ *JI Tata Bumi No 3, Sleman, Yogyakarta, Indonesia; e-mail: ayunquroti@yahoo.com
}

Submisi: 20 Mei 2016; Penerimaan: 8 Juni 2016

\begin{abstract}
ABSTRAK
Faktor risiko karies pada anak terdiri atas faktor risiko langsung, yaitu keadaan rongga mulut anak, dan faktor tidak langsung, yaitu perilaku ibu dan lingkungan. Tujuan penelitian adalah untuk mengetahui faktor-faktor yang berpengaruh terhadap risiko terjadinya karies. Jenis penelitian ini adalah observasional dengan rancangan cross-sectional. Sampel sebanyak 430 anak berumur 10-12 tahun, faktor risiko karies yang diukur adalah pH saliva, banyaknya plak, dan pengalaman karies, perilaku ibu dalam pemanfaatan pelayanan kesehatan gigi anak, perilaku ibu dalam pemeliharaan kesehatan gigi, dan perilaku ibu dalam pemilihan makanan anak. Faktor lingkungan terdiri atas pelaksanaan UKGS oleh guru dan pengaruh teman sebaya. Analisis data dilakukan dengan multiple logistic regression. Hasil analisis menunjukkan $\mathrm{pH}$ saliva $(\mathrm{POR}=1,923)$, banyaknya plak ( $P O R 2,382)$, dan pengalaman karies ( $P O R=4,048)$, perilaku ibu dalam pemanfatan pelayanan kesehatan gigi anak $(P O R=1,876)$, perilaku ibu dalam pemilihan makanan anak $(P O R=1,676)$ dan pelaksanaan UKGS oleh guru $(P O R=1,847)$ berpengaruh secara signifikan dengan risiko karies pada anak $(p<0,05)$. Perilaku ibu dalam pemeliharaan kesehatan gigi anak dan teman sebaya tidak berpengaruh terhadap risiko karies pada anak $(p>0,05)$. Dapat disimpulkan bahwa faktor-faktor yang berpengaruh terhadap risiko karies pada anak adalah pengalaman karies, banyaknya plak, $\mathrm{pH}$ saliva, perilaku ibu dalam pemanfaatan pelayanan kesehatan gigi anak, perilaku ibu dalam pemilihan makanan anak, dan pelaksanaan UKGS oleh guru.
\end{abstract}

Kata kunci: keadaan rongga mulut, lingkungan, perilaku ibu, risiko karies anak

ABSTRACT: The effect of oral cavity condition, mothers' behaviour and environment on the carries risk on children. Carries risk factors in children consist of direct risk factor, which includes the condition of oral cavity, and indirect risk factor including mother's behaviour and environment. The study was to identify factors that influence the occurrence of caries in children. This is an observational research with a cross-sectional design. The samples were 430 children between the ages of 10-12 years. The evaluated caries risk factors included $\mathrm{pH}$ level of saliva, the amount of plaque, caries experience, the mother's behaviour in child's utilization of dental health service, the mother's behaviour on the child's health care, and the mother's behaviour on child's food selection. The environment factors were UKGS implementation by teacher and friend's influences. The data were analysed using multiple logistic regression. The result of multiple logistic regression analysis indicated that the $\mathrm{pH}$ level of saliva $(P O R=1.923)$, the amount of plaque $(P O R=2.382)$, caries experience ( $P O R=4.048)$, mother's behaviour in child's utilization of dental health service $(P O R=2.107)$, mother's behaviour on child's food selection ( $P O R=1.676)$, and the UKGS implementation by teacher $(P O R=1,846)$ significantly influenced the occurrence of caries $(p<0,05)$. The mother's behaviour on the child's health care and friend's influences did not significantly influenced the occurrence of caries $(p>0,05)$. The study showed that $\mathrm{pH}$ level of saliva, the amount of plaque, caries experience, the mother's behaviour in utilization of dental health service, mother's behaviour on child's food selection, and the UKGS implementation by teacher influenced the risk of caries in children.

Keywords: condition of oral cavity, environment, mother's behavior, caries risk in children

\section{PENDAHULUAN}

Karies gigi adalah salah satu penyakit gigi dan mulut pada dan sebagian besar terjadi karena gigi tidak dilakukan perawatan, sehingga berdampak pada gangguan pertumbuhan dan perkembangan anak. ${ }^{1}$ Hal tersebut antara lain, karena kurangnya 
pemahaman dalam pemeliharaan kesehatan gigi dan mulut. ${ }^{2}$ Karies gigi merupakan penyakit multifaktorial yang disebabkan faktor langsung dan tidak langsung. Faktor-faktor yang berperan langsung dalam proses karies adalah plak gigi, mikroorganisme, dan pola makan karbohidrat. Selain itu, proses terjadinya karies tersebut juga membutuhkan waktu. Faktor tidak langsung yang berperan dalam terjadinya karies antara lain adalah sosioekonomi, perilaku, dan lingkungan. Prevalensi karies gigi lebih tinggi terjadi pada anak yang berasal dari status sosial yang rendah, antara lain disebabkan oleh kunjungan ke pelayanan kesehatan gigi yang masih rendah. ${ }^{3}$

Lingkungan anak berpengaruh terhadap risiko terjadinya karies, antara lain sekolah dan teman sebaya. ${ }^{3}$ Salah satu lingkungan sekolah yang berperan dalam membentuk perilaku anak dalam memelihara kesehatan gigi adalah pelaksanaan Usaha Kesehatan Gigi Sekolah (UKGS). ${ }^{4}$ Salah satu kegiatannya adalah melakukan tindakan preventif karies gigi. Usaha Kesehatan Gigi Sekolah menitikberatkan pada upaya penyuluhan dan gerakan sikat gigi massal serta pemeriksaan kesehatan gigi dan mulut pada setiap murid. ${ }^{5}$ Teman sebaya berpengaruh terhadap perilaku anak dalam menjaga kesehatan gigi dan mulutnya. ${ }^{6}$ Tujuan penelitian ini adalah untuk mengetahui pengaruh rongga mulut anak, perilaku ibu dan faktor lingkungan sekolah terhadap risiko terjadinya karies pada anak.

\section{METODE PENELITIAN}

Jenis penelitian adalah observasional dengan rancangan cross-sectional analitik. Subjek penelitian diambil sebanyak 430 anak berusia 10-12 tahun di wilayah Propinsi Daerah Istimewa Yogyakarta dan cara pengambilan data dengan stratified random sampling. Kriteria inklusi pada penelitian ini adalah anak yang mempunyai karies, bersedia ikut dalam penelitian dan telah mendapat persetujuan dari orangtua. Penelitian dilakukan setelah mendapat ethical clereance dari Unit Etik dan Advokasi FKG UGM.
Pengukuran faktor keadaan rongga mulut pada penelitian ini menggunakan bahan penelitian: 1) Disclosing solution, 2) Cotton swab, dan 3) Pasta gigi. Alat yang digunakan adalah: 1) $\mathrm{pH}$ meter, 2) Gelas kecil, 3) Alat diagnostik gigi: pinset, sonde, ekskavator, dan kaca mulut, dan 4) Format penilaian indeks DMF-T/def-t, dan PHPM. Instrumen pengukuran perilaku ibu menggunakan kuesioner, yaitu perilaku ibu dalam pemanfaatan pelayanan kesehatan terdiri atas satu pertanyaan, Perilaku ibu dalam pemanfaatan pelayanan kesehatan terdiri atas delapan pertanyaan, dan perilaku ibu dalam pemilihan makanan anak terdiri atas tujuh pertanyaan. Kuesioner lingkungan terdiri atas pelaksanaaan UKGS oleh guru sebanyak tiga pertanyaan, dan teman sebaya sebanyak empat pertanyaan. Kriteria faktor risiko karies pada anak dapat dilihat pada Tabel 1.

Tabel 1. Kriteria dan batas katagori faktor risiko karies

\begin{tabular}{|c|c|c|}
\hline Faktor risiko & Kriteria & $\begin{array}{c}\text { Batas } \\
\text { katagori }\end{array}$ \\
\hline \multirow[t]{2}{*}{ pH saliva } & Tinggi & $\geq 6,5$ \\
\hline & Rendah & $<6,5$ \\
\hline \multirow{2}{*}{$\begin{array}{l}\text { Banyaknya plak /Indeks } \\
\text { PHPM }\end{array}$} & Tinggi & $>30$ \\
\hline & Rendah & $\leq 30$ \\
\hline \multirow{2}{*}{$\begin{array}{l}\text { Pengalaman karies /Indeks } \\
\text { def-t dan DMF-T }\end{array}$} & Tinggi & $\geq 3$ \\
\hline & Rendah & $\leq 3$ \\
\hline \multirow{2}{*}{$\begin{array}{l}\text { Perilaku ibu dalam peman- } \\
\text { faatan pelayanan kesehatan }\end{array}$} & Baik & $\geq 2$ \\
\hline & Buruk & $<2$ \\
\hline \multirow{2}{*}{$\begin{array}{l}\text { Perilaku ibu dalam peme- } \\
\text { liharaan kesehatan gigi anak }\end{array}$} & Baik & $17-24$ \\
\hline & Buruk & $0-16$ \\
\hline \multirow{2}{*}{$\begin{array}{l}\text { Perilaku ibu dalam pemilihan } \\
\text { makanan anak }\end{array}$} & Baik & $16-21$ \\
\hline & Buruk & $0-15$ \\
\hline \multirow[t]{2}{*}{ Pelaksanaaan UKGS oleh guru } & Baik & 3 \\
\hline & Buruk & $0-2$ \\
\hline \multirow[t]{2}{*}{ Pengaruh teman sebaya } & Baik & $3-4$ \\
\hline & Buruk & $0-2$ \\
\hline
\end{tabular}

Untuk mengetahui pengaruh faktor - faktor rongga mulut, perilaku ibu dan lingkungan terhadap terjadinya karies pada anak, data dianalisa dengan chi-square dan multiple logistic regression. 


\section{HASIL PENELITIAN}

Sampel pada penelitian ini berjumlah 430 anak, terdiri atas 218 anak berjenis kelamin lakilaki $(50,69 \%)$ dan 212 anak berjenis kelamin perempuan $(49,31 \%)$. Pendidikan ibu tergolong rendah, yaitun SD dan SMP $(5,81 \%$ dan $51,86 \%)$, dan pendapatan keluarga tergolong rendah (<Rp1000.000) sebanyak 53,95\% (Tabel 2).

Tabel 2. Karakteristik anak dan ibu

\begin{tabular}{llc}
\hline Karakteristik & \multicolumn{2}{c}{ Jumlah } \\
\cline { 2 - 3 } & $\mathrm{n}$ & $\%$ \\
\hline Jenis kelamin & 218 & 50,69 \\
Laki-laki & 212 & 49,31 \\
Perempuan & & \\
Pendidikan ibu & 25 & 5.81 \\
SD & 223 & 51,86 \\
SMP & 94 & 21,86 \\
SMA & 90 & 20,93 \\
perguruan Tinggi & & \\
Pendapatan Keluarga & 98 & 22,79 \\
Kurang Rp.500.000 & 134 & 31,16 \\
Rp.500.000-Rp.1000.000 & 94 & 21,86 \\
Rp. 1000.000-Rp.2.500.000 & 62 & 14.42 \\
Rp.2.500.000-Rp. 5.000.000 & 42 & 9,77 \\
Lebih Rp. 5 .000.0000 & & \\
\hline
\end{tabular}

Keadaan rongga mulut pada penelitian ini adalah $\mathrm{pH}$ saliva dan sebagian besar bersifat basa $(53,73 \%)$, banyaknya plak $(58,60 \%)$ dan pengalaman karies $(51,86 \%)$. Berdasarkan hasil uji chi-square terdapat hubungan bermakna antara $\mathrm{pH}$ saliva $\left(p=0,001\right.$ dan $\left.X^{2}=12,160\right)$, banyaknya plak $\left(p=0,001\right.$ dan $\left.X^{2}=22,304\right)$, dan pengalaman karies $\left(p=0,000\right.$ dan $\left.X^{2}=37,874\right)$ dengan risiko terjadinya karies pada anak (Tabel 3 ).
Berdasarkan hasil uji chi-square terdapat hubungan bermakna antara perilaku ibu dalam pemanfaatan pelayanan kesehatan gigi $\left(p=0,001\right.$ dan $\left.X^{2}=10,278\right)$, perilaku ibu dalam pemeliharaan kesehatan gigi anak $\left(p=0,001\right.$ dan $\left.X^{2}=11,350\right)$, dan perilaku ibu dalam pemilihan makanan anak $\left(p=0,002\right.$ dan $\left.X^{2}=9,538\right)$ dengan risiko karies pada anak (Tabel 4).

Tabel 5, menunjukkan bahwa terdapat hubungan bermakna antara pelaksanaan UKGS oleh guru $\left(p=0,000\right.$ dan $\left.X^{2}=27,756\right)$ dan pengaruh teman sebaya perilaku $\left(p=0,000\right.$ dan $\left.X^{2}=11,350\right)$, dan perilaku ibu dalam pemilihan makanan anak $(p=0,002$ dan $\left.X^{2}=8,890\right)$ dengan risiko karies pada anak (Tabel 5).

Hasil analisa regresi logistik menunjukkan bahwa faktor keadaan rongga mulut, yang terdiri atas $\mathrm{pH}$ saliva $(p=0,036$ dan $\mathrm{POR}=1,932)$, banyaknya plak $(p=0,005$ dan $\mathrm{POR}=2,382)$ dan pengalaman karies $(p=0,000$ dan $\mathrm{POR}=4,408)$ berpengaruh terhadap risiko terjadinya karies pada anak (Tabel 6).

Faktor perilaku ibu, yang terdiri atas perilaku ibu dalam pemanfaatan pelayanan kesehatan gigi $(p=0,042$ dan $\mathrm{POR}=1,876)$ dan perilaku ibu dalam pemilihan makanan anak $(p=0,048$ dan $\mathrm{POR}=1,676)$ berpengaruh terhadap risiko karies pada anak, sedangkan perilaku ibu dalam pemeliharaan kesehatan gigi anak $(p=0,074)$ tidak berpengaruh secara signifikan terhadap risiko karies pada anak (Tabel 6).

Tabel 6, menunjukkan bahwa faktor lingkungan yang terdiri atas pelaksanan UKGS oleh guru $(p=0,047$ dan $\mathrm{POR}=0,847)$ berpengaruh secara segnifikans terhadap risiko karies pada anak, sedangkan teman sebaya tidak berpengaruh secara signifikans $(p=0,402)$.

Tabel 3. Hasil analisis chi-square faktor kedaan rongga mulut dengan risiko karies pada anak usia sekolah

\begin{tabular}{|c|c|c|c|c|c|c|c|}
\hline \multirow[t]{3}{*}{ Faktor risiko } & \multirow[t]{3}{*}{ Kriteria } & \multicolumn{4}{|c|}{ Risiko Karies } & \multirow[t]{3}{*}{$p$-value (sig) } & \multirow[t]{3}{*}{$x^{2}$} \\
\hline & & \multicolumn{2}{|c|}{ Rendah } & \multicolumn{2}{|c|}{ Tinggi } & & \\
\hline & & $\mathrm{n}$ & $\%$ & $\mathrm{n}$ & $\%$ & & \\
\hline \multirow[t]{2}{*}{$\mathrm{pH}$ saliva } & Tinggi & 58 & 25,11 & 173 & 74,89 & 0,001 & 12,160 \\
\hline & Rendah & 12 & 12,06 & 173 & 87,94 & & \\
\hline \multirow[t]{2}{*}{ Banyaknya plak } & Tinggi & 29 & 11,51 & 223 & 88,29 & 0,001 & 22,304 \\
\hline & Rendah & 53 & 29,78 & 125 & 70,22 & & \\
\hline \multirow[t]{2}{*}{ Pengalaman karies } & Tinggi & 18 & 8,07 & 205 & 91,93 & 0,001 & 37,874 \\
\hline & Rendah & 64 & 30,92 & 143 & 69,08 & & \\
\hline
\end{tabular}


Tabel 4. Hubungan faktor perilaku ibu dengan risiko karies pada anak usia sekolah

\begin{tabular}{|c|c|c|c|c|c|c|c|}
\hline \multirow[t]{3}{*}{ Faktor risiko } & \multirow[t]{3}{*}{ Kriteria } & \multicolumn{4}{|c|}{ Risiko Karies } & \multirow{3}{*}{$\begin{array}{l}p \text {-value } \\
\text { (sig) }\end{array}$} & \multirow[t]{3}{*}{$x^{2}$} \\
\hline & & \multicolumn{2}{|c|}{ Rendah } & \multicolumn{2}{|c|}{ Tinggi } & & \\
\hline & & $\mathrm{n}$ & $\%$ & $\mathrm{n}$ & $\%$ & & \\
\hline \multirow{2}{*}{$\begin{array}{l}\text { Perilaku ibu dalam pemanfaatan pelayanan } \\
\text { kesehatan gigi anaknya }\end{array}$} & Baik & 39 & 28,06 & 100 & 71.94 & \multirow[t]{2}{*}{0,001} & \multirow[t]{2}{*}{10,278} \\
\hline & Buruk & 43 & 14,78 & 248 & 85,22 & & \\
\hline \multirow[t]{2}{*}{ Perilaku ibu dalam pemeliharaan kesehatan gigi } & Baik & 63 & 24,23 & 197 & 75,77 & \multirow[t]{2}{*}{0,001} & \multirow[t]{2}{*}{11,350} \\
\hline & Buruk & 19 & 11,18 & 151 & 88,82 & & \\
\hline \multirow[t]{2}{*}{ Perilaku ibu dalam pemilihan makanan anak } & Baik & 52 & 25,12 & 155 & 74,88 & \multirow[t]{2}{*}{0,002} & \multirow[t]{2}{*}{9,538} \\
\hline & Buruk & 30 & 13,45 & 193 & 86,55 & & \\
\hline
\end{tabular}

$p<0,05$

Tabel 5. Hubungan faktor lingkungan dengan risiko karies pada anak usia sekolah

\begin{tabular}{|c|c|c|c|c|c|c|c|}
\hline \multirow[t]{3}{*}{ Faktor risiko } & \multirow[t]{3}{*}{ Kriteria } & \multicolumn{4}{|c|}{ Risiko Karies } & \multirow{3}{*}{$\begin{array}{l}p \text {-value } \\
\text { (sig) }\end{array}$} & \multirow[t]{3}{*}{$x^{2}$} \\
\hline & & \multicolumn{2}{|c|}{ Rendah } & \multicolumn{2}{|c|}{ Tinggi } & & \\
\hline & & $\mathrm{n}$ & $\%$ & $\mathrm{n}$ & $\%$ & & \\
\hline \multirow[t]{2}{*}{ Pelaksanaan UKGS oleh guru } & Baik & 53 & 31,74 & 114 & 68,26 & 0,001 & 27,756 \\
\hline & Buruk & 29 & 11,03 & 234 & 88,97 & & \\
\hline \multirow[t]{2}{*}{ Pengaruh teman sebaya } & Baik & 50 & 24,13 & 149 & 74,87 & 0,001 & 8,890 \\
\hline & Buruk & 32 & 13,85 & 199 & 86,15 & & \\
\hline
\end{tabular}

Tabel 6. Hasil analisis regresi logistik faktor keadaan rongga mulut dan perilaku pada anak usia sekolah

\begin{tabular}{|c|c|c|c|c|c|}
\hline Variabel & B & $p$ & POR & $95 \% \mathrm{Cl}$ & \\
\hline $\mathrm{pH}$ saliva & 0,658 & 0,036 & 1,932 & 1,046 & 3,568 \\
\hline Banyaknya plak & 0,868 & 0,005 & 2,382 & 1,301 & 4,365 \\
\hline Pengalaman karies & 1,398 & 0,000 & 4,048 & 2,137 & 7,668 \\
\hline Perilaku ibu dalam pemanfaatan pelayanan kesehatan gigi & 0,629 & 0,042 & 1,876 & 1,024 & 3,436 \\
\hline Perilaku ibu dalam pemeliharaan kesehatan gigi anak & 0,599 & 0,074 & 1,819 & 0,944 & 3,507 \\
\hline Perilaku ibu dalam pemilihan makanan anak & 0,516 & 0,048 & 1,676 & 1,012 & 3,034 \\
\hline Pelaksanaan UKGS oleh guru & 0,613 & 0,047 & 1,847 & 1,009 & 3,381 \\
\hline Pengaruh teman sebaya & 0,256 & 0,402 & 1,292 & 0,709 & 2.251 \\
\hline Konstanta & $-2,335$ & 0,000 & - & - & - \\
\hline \multicolumn{6}{|l|}{-2Log likelihood = 146.7813} \\
\hline$=0,299$ & & & & & \\
\hline$=0,026$ & & & & & \\
\hline
\end{tabular}

Keterangan:

$\begin{array}{ll}\text { POR } & : \text { Prevalence Odds Ratio } \\ \mathrm{Cl} & \text { : Confidence internal }\end{array}$

Analisis data perilaku ibu dalam pemeliharaan kesehatan gigi dan mulut anak menunjukkan sebagian besar ibu mengingatkan anak untuk menyikat gigi sesudah sarapan (64\%) dan sebelum tidur $(77 \%)$. Sebanyak $62 \%$ ibu menyediakan

pasta gigi di rumah dan $65 \%$ ibu mengingatkan anak untuk mengurangi makanan yang manis dan melekat. Selain itu sejumlah $73 \%$ ibu tidak memberi contoh menyikat gigi dan $59 \%$ ibu tidak mengantar anak untuk periksa ke dokter gigi (Tabel 7). 
Tabel 7. Distribusi perilaku ibu dalam pemeliharaan kesehatan gigi dan mulut anak

\begin{tabular}{lllll}
\hline Perilaku ibu & \multicolumn{2}{c}{ Ya } & \multicolumn{2}{c}{ Tidak } \\
\cline { 2 - 5 } & $\mathrm{N}$ & $\%$ & $\mathrm{n}$ & $\%$ \\
\hline Memberi contoh cara menyikat gigi yang benar & 116 & 27 & 314 & 73 \\
Mengingatkan menyikat gigi setelah sarapan & 275 & 64 & 155 & 36 \\
Mengingatkan menyikat gigi sebelum tidur & 331 & 77 & 99 & 23 \\
Memeriksa gigi anak di rumah & 194 & 45 & 236 & 55 \\
Mengantar periksa anak ke dokter gigi & 174 & 41 & 254 & 59 \\
Mengganti sikat gigi secara rutin & 228 & 53 & 221 & 47 \\
Menyediakan pasta gigi berfluor & 267 & 62 & 163 & 38 \\
Memberi nasehat anak untuk mengurangi makanan yang manis dan melekat. & 280 & 65 & 150 & 35 \\
\hline
\end{tabular}

Hasil analisis data perilaku ibu dalam pemilihan makanan anak dalam menunjukkan bahwa $90 \%$ ibu telah memberikan sayur setiap makan dan $64 \%$ ibu memberikan buah setelah selesai makan, sedangkan $58 \%$ ibu tidak memberi bekal makanan ke sekolah, dan $63 \%$ ibu membuatkan minum anak dengan gula. Perilaku ibu dalam menyediakan makanan menunjukkan $64 \%$ tidak menyediakan makanan manis dan $72 \%$ tidak menyediakan minuman bersoda (Tabel 8).

Sebanyak $56 \%$ anak mengatakan bahwa sekolah tidak melakukan kegiatan menyikat gigi secara rutin dan $53 \%$ anak berpendapat bapak atau ibu guru tidak memberikan contoh menyikat gigi yang benar. Sebagaian besar anak $(74 \%)$ mengatakan bahwa bapak dan ibu guru memberi nasehat tentang makanan yang baik untuk kesehatan gigi (Tabel 9).
Tabel 10 menunjukkan bahwa 54\% anak menganggap bahwa teman tidak pernah bercerita tentang makanan yang merusak gigi, tidak membicarakan tentangmenyikatgigiyang baik ( $51 \%)$, dan pengalaman periksa ke dokter gigi yang menyenangkan $(56 \%)$.

\section{PEMBAHASAN}

Hasil penelitian menujukkan bahwa distribusi $\mathrm{pH}$ saliva $>6,5$ sebanyak $53,72 \%$. Hasil ini sesuai dengan penelitian terdahulu, yaitu pada anak usia 10-12 tahun $\mathrm{pH}$ saliva bersifat basa atau tinggi. ${ }^{7}$ Hal itu karena sekresi saliva pada anak yang cukup tinggi, sehingga berdampak pada volume saliva yang tinggi pula. ${ }^{8}$ Salah satu fungsi saliva adalah berperan sebagai buffer yang membantu menetralkan $\mathrm{pH}$ saliva sesudah makan, sehingga apabila volume tinggi, maka akan terjadi keseimbangan $\mathrm{pH}$ saliva dan mengurangi terjadinya demineralisasi. ${ }^{9}$

Tabel 8. Distribusi perilaku ibu dalam pemilihan makanan anak

\begin{tabular}{lcccc}
\hline Perilaku ibu & \multicolumn{2}{c}{ Ya } & \multicolumn{3}{c}{ Tidak } \\
\cline { 2 - 5 } & $\mathrm{n}$ & $\%$ & $\mathrm{n}$ & $\%$ \\
\hline Memberikan sayur setiap makan & 387 & 90 & 43 & 10 \\
Memberikan buah selesai anak makan & 275 & 64 & 155 & 36 \\
Memberi bekal makan siang & 181 & 42 & 249 & 58 \\
Membuatkan minum anak dengan gula & 271 & 63 & 159 & 37 \\
Menyediakan kue dan makanan manis di rumah & 155 & 36 & 275 & 64 \\
Memberikan softdrink / minuman bersoda manis untuk putra/putrinya & 120 & 28 & 310 & 72 \\
\hline
\end{tabular}

Tabel 9. Distribusi pelaksanaan UKGS oleh guru

\begin{tabular}{lllll}
\hline & \multicolumn{3}{c}{ Ya } & \multicolumn{2}{c}{ Tidak } \\
\cline { 2 - 5 } & $\mathrm{n}$ & $\%$ & $\mathrm{n}$ & $\%$ \\
\hline Kegiatan menyikat gigi secara rutin & 189 & 44 & 241 & 56 \\
Pemberian contoh sikat gigi yang benar dari guru & 202 & 47 & 228 & 53 \\
Nasehat tentang makana yang baik untuk kesehatan gigi & 318 & 74 & 112 & 26 \\
\hline
\end{tabular}


Tabel 10. Distribusi Pengaruh Teman Sebaya

\begin{tabular}{|c|c|c|c|c|}
\hline & \multicolumn{2}{|c|}{ Ya } & \multicolumn{2}{|c|}{ Tidak } \\
\hline & $\mathrm{n}$ & $\%$ & $\mathrm{n}$ & $\%$ \\
\hline Makanan yang merusak gigi & 198 & 46 & 332 & 54 \\
\hline Contoh menyikat gigi yang baik & 211 & 49 & 219 & 51 \\
\hline Pengalaman ke dokter gigi itu menyenangkan & 189 & 44 & 241 & 56 \\
\hline
\end{tabular}

Banyaknya plak yang tinggi (Indeks PHPM>30), menunjukkan bahwa sebagian besar anak mempunyai oral hygiene yang buruk. ${ }^{4}$ Banyaknya plak berpengaruh terhadap risiko karies. Plak adalah salah satu faktor risiko karies karena berisi deposit lengket bakteri dan produk-produknya yang terbentuk dan menempel pada permukaan gigi. Apabila plak tidak dibersihkan mengakibatkan penurunan $\mathrm{pH} .{ }^{10}$ Plak pada permukaan gigi bersifat asam selama beberapa waktu. Untuk kembali ke $\mathrm{pH}$ normal sekitar 7 , membutuhkan waktu 3060 menit.11 Plak pada permukaan gigi yang tidak segera dibersihkan mengakibatkan penurunan $\mathrm{pH}$ plak dan apabila melampaui batas kritis menyebabkan demineralisasi email berupa bercak putih atau white spot, dan apabila terus berlanjut, mengakibatkan karies gigi. ${ }^{12}$

Pengalaman karies merupakan penjumlahan indeks DMF-T dan def-t berpengaruh terhadap risiko karies pada anak. Hasil ini sesuai dengan penelitian terdahulu bahwa anak yang mempunyai pengalaman karies yang tinggi, pada usia berikutnya akan menderita karies yang tinggi pula. ${ }^{13}$ Gigi yang mengalami karies terdapat lebih banyak bakteri yang akan menghasilkan asam, sehingga terjadi penurunan $\mathrm{pH}$ plak yang lebih besar dibanding gigi yang tidak mengalami karies. ${ }^{14}$

Perilaku ibu berpengaruh positif terhadap risiko karies pada anak, yaitu semakin buruk perilaku ibu, semakin tinggi risiko karies. Hasil penilitian ini sesuai dengan perilaku sebagian besar lbu (58\%) tidak pernah memberi bekal sekolah pada anaknya, sehingga anak cenderung mengkonsumsi makanan kariogenik yang disediakan di kantin sekolah. Hal tersebut didukung hasil survey pada 94 warung sekolah di SD wilayah Kabupaten Sleman yang menyediakan makanan kariogenik. ${ }^{15}$ Perilaku ibu yang buruk dalam penyediaan makanan anak, karena ibu cenderung menyediakan makan yang disukai anak-anak, yaitu makanan kariogenik. ${ }^{16}$ Hasil penelitian yang berbeda menunjukkan bahwa perilaku ibu yang buruk bukan merupakan faktor risiko karies pada anak, karena anak-anak melakukan pembersihan gigi dan mulut secara rutin dan benar. ${ }^{17}$

Dalam penelitian ini, perilaku ibu dalam pemanfaatan pelayanan kesehatan gigi anak berpengaruh positif dan signifikan terhadap risiko karies pada anak. Artinya, semakin buruk pemanfaatan pelayanan kesehatan gigi anak oleh ibu, semakin tinggi risiko karies pada anak. Peran orangtua dalam pencegahan terjadinya karies pada anak usia sekolah adalah dengan melakukan pemeriksaan rutin ke pelayanan kesehatan gigi. ${ }^{3}$ Anak usia sekolah masih mempunyai sikap ketergantungan pada ibu, sehingga ibu yang paling berperan dalam mengantar anak periksa ke dokter gigi. ${ }^{18}$ Hasil analisis menunjukkan bahwa lebih dari separuh jumlah ibu mempunyai periilaku yang buruk dalam pemanfaatan pelayanan kesehatan gigi anak (kunjungan kurang dari dua kali dalam setahun). Hal tersebut karena sejumlah $59 \%$ ibu tidak pernah mengajak anak untuk periksa ke dokter gigi). Hasil ini didukung oleh distribusi faktor pengaruh teman sebaya, yakni $56 \%$ anak beranggapan bahwa teman-temannya tidak menceritakan bahwa periksa ke dokter gigi itu menyenangkan. Anak akan termotivasi dan meminta orangtuanya untuk mengantar periksa ke dokter gigi, jika mendapat cerita dari teman sebaya bahwa periksa ke dokter gigi itu menyenangkan dan tidak menakutkan. ${ }^{19}$

Motivasi untuk kontrol atau periksa ke dokter terjadi apabila seseorang mempunyai pengalaman yang tidak diinginkan tentang penyakitnya. ${ }^{20}$ Orangtua maupun anak akan memeriksakan ke dokter gigi, jika anak merasa terganggu dengan kesehatan gigi dan mulutnya. ${ }^{21}$ Dokter gigi selalu menekankan pentingnya memelihara kesehatan 
gigi pada anak yang sering melakukan kontrol ke dokter gigi, sehingga akan berdampak pada oral hygiene anak yang baik pula. ${ }^{22}$

Selain hal tersebut, pemanfaatan pelayanan kesehatan gigi juga dipengaruhi oleh tingkat pendidikan dan keadaan sosial ekonomi. ${ }^{3,23}$ Sebanyak $57,67 \%$ ibu mempunyai tingkat pendidikan yang tergolong rendah, yaitu SD dan SMP. Pendidikan ibu yang rendah memengaruhi kemampuan orangtua dalam mengakses informasi dan pemahaman mengenai manfaat perawatan kesehatan gigi dan mulut bagi anak. Dengan demikian, hal tersebut akan menimbulkan motivasi dan sikap yang kurang baik terhadap perawatan kesehatan gigi dan mulut anak. ${ }^{19}$ lbu yang tidak peduli terhadap kesehatan gigi, tidak akan memperhatikan kesehatan gigi anaknya, sehingga status kesehatan gigi dan mulut anak akan buruk pula. ${ }^{24}$

Tingkat pemanfaatan pelayanan kesehatan gigi anak usia sekolah dipengaruhi juga oleh tingkat pendapatan orangtua. ${ }^{25}$ Penelitian ini menunjukan $53,95 \%$ orangtua mempunyai tingkat pendapatan yang tergolong rendah (kurang dari Rp.1.000.000). Hasil penelitian terdahulu menunjukkan bahwa semakin tinggi pendapatan keluarga, maka semakin baik pula tingkat pemanfaatan pelayanan kesehatan gigi pada anaknya. ${ }^{22}$

Selain faktor perilaku ibu, faktor lingkungan sekolah, yaitu pelaksanaan UKGS oleh guru berpengaruh positif dan signifikan terhadap risiko karies pada anak usia sekolah. Artinya, semakin buruk pelaksanaan UKGS, semakin tinggi risiko karies pada anak sekolah. Buruknya pelaksanaan UKGS oleh guru berdampak terhadap risiko karies pada anak karena $56 \%$ anak mengatakan sekolah tidak pernah melaksanakan kegiatan menyikat gigi bersama. Selain itu, $53 \%$ anak berpendapat bahwa bapak dan ibu guru tidak memberikan contoh menyikat gigi yang benar. Hasil penelitian ini sesuai dengan hasil penelitian terdahulu bahwa pelaksanaan UKGS belum dilaksanakan dengan baik. ${ }^{26}$ Hal tersebut, karena penyuluhan kesehatan gigi belum dijalankan oleh guru karena materi, alat peraga, dan buku pedoman pelaksanaan UKGS tidak tersedia. Selain itu, kegiatan menyikat gigi bersama baru dilaksanakan satu bulan sekali. Tindakan pencabutan dan penumpatan gigi tidak dilakukan, karena tidak ada jadwal UKGS dari puskesmas. Kegiatan yang selama ini telah dilaksanakan oleh sekolah dalam program UKGS adalah melakukan rujukan ke puskesmas atau dokter gigi. ${ }^{27}$

UKGS menitikberatkan pada upaya penyuluhan, kegiatan menyikat gigi bersama dan pemeriksaan gigi dan mulut secara rutin. Oleh karena itu, guru di sekolah perlu mengajarkan pada murid-muridnya metode menyikat gigi yang benar. ${ }^{5}$ Guru perlu mengingatkan tentang frekuensi menyikat gigi paling sedikit dua kali sehari, yaitu sebelum tidur dan sesudah sarapan, dan setiap menyikat gigi selalu menggunakan pasta gigi berfluor. Pelaksanaan UKGS diharapkan mampu memengaruhi dan memotivasi anak usia sekolah dalam memelihara kesehatan giginya, sehingga diharapkan risiko karies akan turun. ${ }^{4}$ Informasi tentang kesehatan gigi dan mulut pada anak diperoleh di antaranya dari guru di sekolah. ${ }^{28}$ Peran dan dukungan dari komponen sekolah, terutama guru, sangat menentukan keberhasilan program kesehatan sekolah. Hal tersebut karena informasi dari guru dapat terjadi secara langsung pada anak maupun tidak langsung melalui orangtuanya. ${ }^{29}$

Sebagian besar perilaku ibu $(60,47 \%)$ dalam pemeliharaan kesehatan gigi anak adalah baik dan tidak berpengaruh terhadap risiko karies. Hal ini terjadi kemungkinan karena anak pada usia sekolah sudah mulai berinteraksi dengan dunia luar terutama media elektronik. Anak akan lebih banyak mendapat informasi tentang pemeliharaan kesehatan gigi dan mulut melalui program kesehatan gigi di televisi, koran, dan majalah. ${ }^{30}$

Hasil penelitian ini menunjukkan bahwa lebih dari separuh jumlah anak (53,73\%) menganggap bahwa pengaruh teman sebaya dalam pemeliharaan kesehatan gigi adalah rendah. Hasil analisis regresi logistik diperoleh bahwa teman sebaya tidak berpengaruh terhadap risiko karies $(p=0,402)$. Berbeda dengan anak remaja yang menjadikan teman sebaya sebagai sumber kognitif dan emosional, sehingga perilaku teman sebaya akan lebih banyak berpengaruh pada pola 
pikir dan perilakunya. Hasil penelitian ini, tidak sesuai dengan terdahulu yang mengatakan bahwa teman sebaya merupakan faktor yang berpengaruh terhadap status kesehatan gigi anak usia sekolah. ${ }^{25}$ Penelitian sebelumnya menunjukkan bahwa perilaku teman sebaya berpengaruh terhadap status kesehatan gigi dan mulut, terutama dalam hal kebiasaan makan. Kebiasaan makan yang baik pada masa anak akan membentuk pola makan yang baik pula di kemudian hari. ${ }^{31}$

\section{KESIMPULAN}

Berdasarkan penelitian yang telah dilakukan, dapat diambil kesimpulan bahwa faktor keadaan rongga mulut yang terdiri atas $\mathrm{pH}$ saliva, banyaknya plak, dan pengalaman karies, perilaku ibu dalam pemanfaatan pelayanan kesehatan gigi dan pemilihan makanan anak, dan pelaksanaan UKGS secara statistik berpengaruh terhadap risiko terjadinya karies pada anak. Terdapat banyak faktor lingkungan yang belum diukur pada penelitian ini, oleh karena itu pada penelitian selanjutnya disarankan untuk meneliti faktor lingkungan keluarga antara lain jumlah anggota keluarga, tipe pengasuhan, dan faktor di masyarakat antara lain pengaruh asuransi terhadap risiko karies pada anak.

\section{UCAPAN TERIMAKASIH}

Peneliti mengucapkan terimakasih kepada 16 kepala SD di wilayah DIY yang telah memberi ijin untuk mengadakan penelitian. Demikian juga ucapan terimaksih saya sampaikan kepada anak kelas V SD di wilayah Propinsi DIY yang telah bersedia menjadi responden penelitian, dan kepada orangtua siswa yang telah memberikan ijin pengambilan data pada putra-putranya.

\section{DAFTAR PUSTAKA}

1. Martine CM, Ebert W, Irene HA, Johanna MB, Jacob M, Johannes J. The influence of dental caries on body growth in pubertal children. Clin Oral Invest. 2011; 15: 144 - 149.
2. Sriyono NW. Pencegahan penyakit gigi dan mulut guna meningkatkan kualitas hidup. Pidato pengukuhan jabatan guru besar, Fakultas Kedokteran Gigi, Universitas Gadjah Mada, Yogyakarta. 2009.

3. Fisher-owens SA, Gansky SA, Platt LJ, Weintraub JA, Soobader MJ, Bramlett MD, Newacheck PW. 2007.p.510-5520. Influences on children's oral health: conceptual model, American Academy of Pediatrics<htpp://pediatrics. Aapublication. org/conten/120/3/e510. full.html>. Diunduh 23 maret 2015.

4. Darwita RR, Novrida H, Budiharto, Pratiwi PD, Amalia R, Asri SR. Improving oral health awareness in primary school student. $\mathrm{J}$ Indon Med Assoc. Mei 2011; 61(5): 204 - 209.

5. Kemenkes. Pedoman usaha kesehatan gigi sekolah (UKGS), Kemenkes, Jakarta; 2012.

6. Rahmawati I. Perilaku kesehatan gigi dan mulut pada anak usia sekolah dasar di Kabupaten Banjar. Thesis, Pogram Pascasarjana, Fakultas kedokteran, Universitas Gadjah Mada, Yogyakarta; 2011.

7. Pinkham JR, Cassamassiomo PS, Field HW, Tigue DJ, Nowak AJ. Pediatric Dentistry, $4^{\text {ed. }}$. St.Louis: Elsevier Saunders; 2005. 469

8. Gudkina J, Brinkame A. Caries experience in relation to oral hygiene, salivary cariogenic microflora, buffer capacity and secretion rate in 6 year olds ad 12 year olds in Riga, Stomatologija. Baltic Dental and Maxillofacial Journal. 2008; 4(20): 76 - 80.

9. Guare RO, Ciamponi AL, Santos MTBR, Garjao R, Diniz MB. Caries experience and salivary parameter among overweght childrend and adolescent. Dentistry Journal. 2013; 1: 31 -36 .

10. Bratthall D, Petersson GH, Stjernsward JR, Cariogram Manual. internet version 2.01<http:/ www. db.od.mah.se/car/cariogram /cariograminf and cheo. Html> (Accessed 23 March 2013). 
11. Hunstad MN, Antonsen GM. Masteroppgave: caries risk assessment, universittet, det helsevitenskapelige fakultet. Institutt for Kliniks Odontologi. 2011; 1 - 16.

12. Kidd EAM. Essential of dental caries. Oxford University Press, New York, USA; 2005. 3 - 7.

13. Cameron AC, Widmer RP. Handbook of Pediatric Dentistry, $3^{\text {rd }}$ Edition, Mosby Elsevier Limited; 2008. 39 - 41.

14. Lian CW, Phing TS, Chat CS, Shin BC, Baharuddin LH, Che'jalil ZBJ. Oral health knowledge, attitude and practice among secondary school student in Kucing Sarawak. Archives of oraofacial Sciences. 2010; 5(1): 9 $-16$.

15. A'yun Q, Ediati $S$, Taadi. Survey penyediaan makanan di kantin SD di wilayah Kabupaten Sleman. Laporan penelitian, JKG Poltekkes, Yogyakarta. 2010; 1 - 12.

16. Maharani DA, Anton R. Mother's dental health behaviors and mother-child dental caries experience: Study of a suburb area in Indonesia. Makara Kesehatan. 2012; 16(2): 72 - 76.

17. Qiu, RM, Wong, MCM, LO, ECM, Lin, HC. Relationship between children's oral healthrelated behaviors and their caregiver's sense of coherence. BMC Public Health. 2013; 12(239): 1 - 7 .

18. Bekiroglu N, Tanboga I, Altinok B, Kargul B. Oral health behaviour in group of Turkish children. Iranian J Pub Health. 2009; 38(4): 125 - 131.

19. Sumanti $V$, Widarsa T, Duarsa DP. Faktor yang berhubungan dengan partisipasi orangtua dalam perawatan gigi anak di Puskesmas Tegalalang I. Public health and Preventive Medicine Archive. 2013; Jul: 1.

20. Browning CJ, Thomas SA. Behavioural change. Elsevier Limited, China; 2005.

21. Zhu L, Petersen PE, Hong YW, Jin YB, Bo $X Z$. Oral health knowledge, attitudes and behaviour of adult in China. International Dental Journal. 2005; 55: 231 - 241.

22. Medina-Solis CE, Maupome G, Herrera MS, Perez-Nunez R, Avila-Burgos L, Lamadrid-
Figueroa $\mathrm{H}$. Dental health service utilization and association factors in children 6 to 12 years old in low-income country. American Association of Public Health Dentistry. 2008; 68: 1.

23. Skaret E, Espelid I, Skeie M, Haugejorden O. Parental beliefs and attitude towards child caries prevention; massessing consistency and validity in longitudinal desing. Biomed Central Oral Health. 2008;1 - 8.

24. Rahman. Socioeconomic status, neighborhood, household behavior, and children's health in the United States: Evidence from children's health survey data, Selected paper prepared for presentation at the American agricultural economics association annual meeting, Orlando, FL. 2008; 27 - 29. 33: 21.

25. Petersen PE, Jiang $H$, Peng B, Tai BJ, Bian $Z$. Oral and general health behaviours among Chinnese urban adolescent, Community Dent Oral Epidemiol. 2008; 36; 76 - 84.

26. Rahmawati I. Perilaku kesehatan gigi dan mulut pada anak usia sekolah dasar di Kabupaten Banjar, Thesis, Pogram Pascasarjana, Fakultas kedokteran, Universitas Gadjah Mada, Yogyakarta; 2011.

27. Ngatemi. Faktor manajemen pelaksanaan UKGS dan peran orangtua terhadap status kesehatn gigi dan mulut murid sekolah dasar. Jurnal Health Quality. 2013; 3(2): 69 - 140.

28. Verenna B, Petersen PE, Outtara S. Oral health behavior of children and adulth in urban in rural areas of Burkina Faso. International Dental Journal. 2008; 58(2): 61 - 70.

29. Feng $\mathrm{P}, \mathrm{He} \mathrm{Y}$. Relathionship between parents attitude and children oral health behavior. Shanghai Kou Qiang Yi Xue. 2005; 14(5): 473 -475 .

30. Fukai K, Yano H, kamachi S, Nakamura S. Oral health status and oral health behavior of school children. Oral Health Behavior dan School health. 2012; 12(2): 146 - 151.

31. Holdford A. Take-up of free school meals: price effect and peer effect, 2012 www.isser.essec. ac.id.uk,. Diunduh pada tanggal 28 Mei 2014. 